\title{
A Review of EFL Arab Learners' Language: Pitfalls and Pedagogical Implications
}

\author{
Yousef Tahaineh $^{1}$ \\ ${ }^{1}$ Al-Balqa' Applied University, Amman, Jordan \\ Correspondence: Yousef Tahaineh, Al-Balqa' Applied University, Amman, Jordan. E-mail: \\ ytahaineh2006@yahoo.com
}

Received: November 14, 2013

Accepted: December 24, 2013 Online Published: January 24, 2014

doi:10.5539/ijel.v4n1p84

URL: http://dx.doi.org/10.5539/ijel.v4n1p84

\begin{abstract}
Nonetheless, that there are distinguished, qualified, specialized and experienced teachers; in addition to good overall designing and planning; comprehensive and purposive curriculum, integrated textbooks, but the achievement is still below the expectations of all who are concerned with English language teaching in the Arab world. The current study is set out to review kinds of pitfalls encountered by EFL Arab Learners at the tertiary level in the use of the most three problematic syntactic/semantic sub-categories: prepositions, articles and discourse markers, respectively, in their written and oral discourse. The aim is twofold, by reviewing the empirical studies conducted in the last two decades, the study seeks to probe, introduce and report first: the most common kinds of pitfalls Arab undergraduates face in learning English as a foreign/second language. Second: to reveal possible sources and causes lie behind these pitfalls and what insights and pedagogical implications might be offered. Pitfalls were discussed, conclusions had been drawn, implications and future directions were provided at the end. This is followed by practical suggestions to minimize the occurrence of pitfalls in their formal English.
\end{abstract}

Keywords: pedagogical implications, EFL context, reviewed studies, Arab learners' pitfalls

\section{Introduction}

Interest in the teaching of English as a global language has been growing throughout the Arab world, and most Arab governments began to introduce the teaching of English as compulsory subject into the school curriculum. At present, in most Arab countries, all students who finish the public secondary school education must have had at least eight years of instruction in English as a school subject. So, because of the widespread use of English as a second language, the subject of language teaching in general and teaching English as a foreign or second language in particular, has become the focus of attention of many Arab researchers (Al-Khatib, 2000). Language is a very important means of communication among human beings. One can communicate his or her desires, ideas, emotions, beliefs or feelings to another as they share the common code that makes up the language. Nobody denies that there are several other means of communication used by human beings, e.g., miming gestures, short-hand, flags, sirens, nods, Braille alphabet, etc. But all these means of communication are extremely limited or they too, in turn, depend upon language. They are not as flexible, comprehensive, perfect and extensive as language is. According to Sapir (1921), "Language is primarily human and non-instinctive method of communicating ideas, emotions and desires by means of a system of voluntarily produced symbols" (as cited in Jindal \& Syal, 1999, p. 4). Language learning process is actually a process of trial and pitfall, in which a learner forms a hypothesis, and later proves it, abort it or adjust it, based on his knowledge of the target language. In the speech or writing of a second/foreign language, pitfall is the use of a linguistic item (e.g., a word, grammatical item, speech act, etc.) in a way which a fluent or native speaker of the language regards as showing faulty or incomplete (Richards, 2002). Corder (1986) define "an error, as a breach of the norms of the target language". According to Collins Cobuild Dictionary (2006) "the pitfalls involved in a particular activity or situation are the things that go wrong or may cause problems". Whereas, the Concise Oxford Dictionary (2001) defines "pitfall" as "a hidden or unsuspected danger or difficulty, a covered pit for use as a trap".

Examining and studying pitfalls in foreign/second language acquisition is important and challenging area of investigation which is still a fertile area requiring much more research? After a systematic exposure of learners to a body of knowledge in English, the teacher, essentially, will want to know the performance or the learning 
outcome of students. He does this by exposing learners to a corresponding body of tests. Language tests help to elicit from language learners the extent to which the taught skills have been mastered. Language testing is, therefore, the systematic process of getting information from learners regarding their levels of acquisition of certain skills (Alderson, 1981; Carroll, 1981). Hence the present study reviewed only the empirical research studies collected data from the field and investigated various problems made by EFL/ESL Arab learners. But, before we start reviewing the previous empirical research studies, let's see what is a pitfall ( an error) and what is the role of Error Analysis in describing the learners' interlanguage, learning/teaching the language, the significance of learners' errors and what are the types of errors.

\subsection{EA in L2 Learning and Teaching}

One of the highly significant contributions of Error Analysis lies in its success in elevating the status of errors from undesirability to that of a guide to the learner's internal processing used for acquiring L2 knowledge and using it for creating speech. With the publication of Corder's (1967) article "The significance of learners' errors", EA emerged as a new theory and methodology of importance to both language pedagogy and the study of language learning. "It is in this Corder's seminal paper that he adds to our thinking by discussing the function of errors for the learners themselves. For learners, errors are 'indispensable,' since the making of errors can be regarded as a device the learner uses in order to learn" (Selinker, 1992, p. 150). George (1972, p. 2) puts it: "at the beginning of the sixties the word 'error' was associated with correction at the end with learning". EA may have the longest history of all methods for analyzing learner's language. Prescriptive grammarians in the 18th century called EA the study of "bad language" in the context of native speaker usage. It is represented in the "King's English" by Fowler (1906) cited in Ellis and Barkhuizen (2005). The purpose of this early approach was to demonstrate what linguistic forms not to use and which ones to use. It continues today, as illustrated in Howard's "Good English Guide" (1994). To fully understand the field of EA, it is necessary to view it in contradistinction to $\mathrm{CA}$ and in relation to its base, the cognitive orientation as opposed to the behaviorist orientation toward language learning and language pedagogy. In the context of foreign/second language pedagogy, a number of books (e.g., Turton \& Heaton, 1996; Swan \& Smith, 2001, among others) elaborating "common errors" arose partly as a criticism of CA, which had proven unable to predict all learner errors, in a time when behaviourism lost ground. EA has become the popular approach to learner errors (Lightbown \& Spada, 2006). EA is a type of linguistic analysis that focuses on the errors learners make. The comparison made in EA is between the errors a learner makes producing the target language and the target language form itself.

Until early seventies, the well-known theory regarding the issue of second language learning was behaviouristic, which suggested that the learning was largely a question of acquiring a set of new language habits. In case of foreign language (FL) learning, the first language (L1) was deemed to be a source of interference and error in case of differences between the two languages, (see e.g., Robert Lado, 1957). Hence, CA gained grounds as a means of predicting areas of similarity and difference between L1 and L2. The fact that not all the differences between L1 and L2 lead to error and that not all errors made by L2 learners are due to the influence of L1 led to the well-deserved liberation of EA from CA and, hence, to the death of predictive CA (Whitman \& Jackson, 1972). Talking about the heyday of EA, James (1998, p. 11) writes, "By the late 1960s EA had become the acceptable alternative to the Behaviorist CA of the 1950s." Thus, the tables were turned; EA became a corporate body subsuming CA under it to play an explanatory role in case of interlingual transfer. EA continued to flourish with the advent of the markedness theory which attributed the degree of difficulty in language learning to the degree of markedness. The more marked a language form is, the more difficult it is to learn (cf. Eckman, 1981). Comrie (1990) and Major and Faudree (1996) indicated that EA benefited from the idea of universal grammar (UG) theory which says that many of rules we internalize when learning L1 are believed to be universal and this leads to a better understanding of the distance between L1 and L2 and the difficulties that FL/SL learners face. As Dessoouky (1990, p. 146) says, EA is "a non-stop area of research". This means when Dessouky published his study in 1990, EA had not lost momentum since the 1960s. Language teaching specialists are still doing their error analyses.

A number of EA studies were conducted in the first decade of the 2000s. The following are only a few examples: Tahaineh (2011); Mahmoud (2011); Abi-Samra (2003); Mourtaga (2004); Bacha (2000); Erdogan (2005); AbuJarad (2008); Al-Nawas (2009); and Darus (2009); As long as people continue to learn language L1 or (FL), they will commit errors, so EA will remain "a non-stop area of research". Nobody goes from zero competence to full competence in the language in one leap. And as long as people commit errors-as opposed to performance slips and mistakes (see Brown, 2000) - there will be a need for EA not only for the traditional purposes of error correction and remedial teaching, but also for what EA can reveal about the process of learning and using language. Error analysis as an approach for studying learners' language has traditionally been used for three 
different purposes: firstly, in second language (L2) acquisition studies where the interlanguage of learners is examined for errors; secondly, as evidence of cross-linguistic infuence from the first language (L1) on the L2; and finally, as an approach used for pedagogical reasons, to point out problematic areas to be focused on in teaching. Error analysis for pedagogical reasons is aimed at giving pedagogical advice on how to deal with different types of errors in learners' language (Gass \& Selinker, 1994). Corder (1986) maintains that errors are significant in three ways: firstly, they can give information to the teacher as to how far the learner has progressed; secondly, they provide the researcher with evidence of how language is learnt, and thirdly, the learner learns by making errors. Thus, the making of errors reflects a strategy used by the learner to test hypotheses about the target language (TL), with the native language (NL) as the reference frame against which the new system is tested.

\subsubsection{The Significance of L2 Learner's Pitfalls}

It is inevitable that learners commit mistakes in the process of foreign language learning. However, what is questioned by language teachers is why students go on making the same mistakes even when such mistakes have been repeatedly pointed out to them. Corder (1986) maintains that errors are significant in three ways: firstly, they can give information to the teacher as to how far the learner has progressed; secondly, they provide the researcher with evidence of how language is learnt, and thirdly, the learner learns by making errors. Thus, the making of errors reflects a strategy used by the learner to test hypotheses about the target language (TL), with the native language (NL) as the reference frame against which the new system is tested. Yet not all mistakes are the same; sometimes they seem to be deeply ingrained, but at other times students correct themselves with ease. Thus, researchers and teachers of foreign language came to realize that the mistakes a person made in the process of constructing a new system of language is needed to be analyzed carefully, for they possibly held in them some of the keys to the understanding of second language acquisition. In this respect, one of the objectives of this study is to point out the significance of learners' errors for they provide evidence of how language is learned and what strategies or procedures the learners are employing in the discovery of language, and to find out reasons and causes stands behind these errors. Corder, showed the importance of EA to the researcher. The theoretical reasons for analysing the errors of second language learners shed light on a theoretical standpoint about language and language learning in both psychological and linguistic dimensions. Richards quotes Corder $(1967$, p. 167) as saying: "the learner errors are indicative both of the state of the learner's knowledge, and the ways in which a second language is learned or acquired" (Richards, 1974, p. 1). Linguists have considered what constitutes an error, lack of grammaticality, acceptability, correctness and felicity (it is the quality of being good, pleasant, or desirable) are criteria for recognizing errors mentioned by James (1998) and other specialists in the field. Clearcut definitions, most of which take into account inappropriateness of use and incompleteness of learning from the point of view of native speakers often lack conceptual clarity (Klassen, 1991; Richards, 1992). The concepts of incompleteness and inappropriateness by native speakers, as suggested by some of these researchers, are problematic in the sense that it is not always native speakers who are the authentic sources of appropriateness and completeness. Having covered the significance of errors makes it feasible to start the process of how to identify an error.

\subsubsection{Identification and Description of Pitfalls_-Variety of Foci}

In the applied linguistics field, the term error is taken to mean some idiosyncratic or "un-nativelike" piece of language produced regularly and systematically by a foreign language learner. Put it in another way, an error is a noticeable deviation from the adult grammar of a native speaker, reflecting the interlanguage of the learner. An error may vary in magnitude. It can include a phoneme, a morpheme, a word, a sentence or even a paragraph. Due to this fact, errors may also be viewed as being either global or local (cited in Brown, 2000). Global errors hinder communication. They prevent the message from being comprehended as in the following example: * "I like bus but my mother said so not that we must be late for school". On the other hand, local errors do not prevent the message from being understood because there is usually a minor violation of one segment of a sentence that allows the hearer to guess the intended meaning as follows: * "If I hear from her, I would let you know". The final group is the two related dimensions of error, domain and extent. Domain is the rank of linguistic unit from phoneme to discourse that must be taken as context in order for the error to be understood, and extent is the rank of linguistic unit that would have to be deleted, replaced, supplied or reordered in order to repair the sentence. This suggestion by Lennon (cited in Brown, 2000) is parallel with Corder's other categorization of overtly and covertly (1973). Overt errors are unquestionably ungrammatical at the sentence level and covert errors are grammatically well-formed at the sentence level but are not interpretable within the context of communication. For example, "I'm fine, thanks." Is a correct sentence but if it is given as an answer to the question of "How old are you?" it is covertly error. Brown (2000) defines errors as "idiosyncrasies in the 
interlanguage of the learner which are the direct manifestation of a system within which a learner is operating at a time". Ellis defines it as "a deviation from the norms of the target language" (Ellis, 1994). However he admits that such a definition raises a number of questions regarding the variety of the target language to be considered as the norm. Corder (1986, p. 65) States: "to identify the presence and nature of an error, an interpretation of the learner's utterance is necessary". In other words, it can reveal the distinctions between "what the learner wants to say" and "what he has said". The plausible interpretation of the learner's utterance by forming a reconstruction of the sentence in the TL, then compare the reconstruction with the original idiosyncratic sentence and then describe the differences. Corder (1986, p. 37) explains it and says "We identify errors by comparing original utterances with what I shall call reconstructed utterances, that is, correct utterances having the meaning intended by the learner". It is, nevertheless, crucial that we make the correct interpretation, as Corder (1986, p. 37) puts it, "since the success of our description depends entirely on the correctness of our interpretation of the learner's intention or meaning".

In addition to the above classifications, for the description of errors, several researchers (Krashen, Dulay, \& Burt, 1982; Dulay \& Burt, 1972; Corder, 1973; Ellis, 1994; Richards, 1971, 1992; Abi-Samra, 2003; Mourtage, 2004; Mohammad, 2005) have identified various error types and suggested frameworks according to the linguistic levels of description and the systematicity. Although Burt, Dulay and Krashen (1982) note that there are two main ways of categorising learners' errors into: (a) Linguistic categories (morphology, syntax, etc.) (b) Surface structure taxonomies (omission, addition, substitution, etc.) Based on the reviewed literature, in actual fact many classifications are hybrid versions such as Corder (1986) who records errors of omission, addition, selection, and ordering on one level, and at the same time distinguish between errors made on the grammar, lexico-semantic and graphology/phonology levels. Corder himself is critical of using the surface structure taxonomy exclusively because it is not sufficiently deep or systematic. As he shows with the following example: * "I am waiting here since three o'clock". Nothing is really explained by stating that the error involves a wrong selection and an omission. It is more important for the learner to know s/he has simply made a tense error (Corder, 1986, p. 37). As far as interpretation is concerned, Corder (1986) reports that there are three types of interpretation of errors: 1) normal - can assign a meaning to an utterance based on the rules of the target language; 2) authoritative-involves asking the learner to say what the utterance means in order to make an authoritative reconstruction; and 3) plausible interpretation - can be obtained by referring to the context in which the utterance was produced or by translating the sentence literally into the learner's L1.Moreover, regarding classification of errors, the current study argues that plethora of related literature has been devoted to the classification of errors on the basis of their sources and has, thus, generated further discussion and debate. This is mainly due to the fact (Abbott, 1980; Obeidat, 1986; Ellis, 1994) that in some cases errors cannot be attributed to a single source: rather, an overlapping of different sources is likely unavoidable. For instance, Abbott (1980, p. 3) points out: "no one can claim to know precisely what causes a particular student to make a particular mistake, the cause may be very complicated or there may be more than one cause". Even the distinction between intralingaul errors and developmental errors, proposed by Richards (1971) is unclear, studies have revealed that almost all developmental errors, as a matter of fact, are intralingaul (Selinker, 1972; Brown, 2000). In other words, although, to date, no published effort has been made that renders errors neatly pigeon-holed. A number of different categories for describing errors have been identified. Firstly, Corder (1973) classifies the errors in terms of the difference between the learners' omission of some required element; addition of some unnecessary or incorrect element; selection of an incorrect element; and misordering of the elements. Nevertheless, Corder himself adds that this classification is not enough to describe errors. That is why he includes the linguistics level of the errors under the sub-areas of morphology, syntax, and lexicon (Corder, 1973). Ellis (1997) maintains that "classifying errors in these ways can help us to diagnose learners' learning problems at any stage of their development and to plot how changes in error patterns occur over time."

\subsubsection{Pitfalls: Errors vs. Mistakes}

First step in error analysis we have to make a clear distinction between what are Pitfalls: the things that go wrong or may cause problems (errors) on the one hand and lapses and slips (mistakes) on the other hand. In the Applied Linguistics field, the term "error" is taken to mean some idiosyncratic or "un-nativelike" piece of language produced regularly and systematically by a foreign language learner According to Corder's definition (1986), which is partially traced back to the Chomskyian dichotomy between "competence" and "performance", according to Chomsky speaker-hearer's internal grammar. Also Chomsky (1986) proposed a distinction between "I (internal)-language" and "E (external)-language", which is similar to the competence/performance distinction. Corder (1986, p. 10) makes a distinction between "errors" as systematic and competence-based, and "mistakes" as unsystematic and performance-based. He maintains that the term "error" should refer to "the systematic errors 
of the learner from which we are able to reconstruct his knowledge of the language to date, i.e., his transitional competence. He uses the term systematic to identify errors, and asserts that the difference between systematic and non-systematic has an important significance. Non-systematic refers to performance of the L2 learner due to random guess, memory lapses, physical conditions, slip of tongue/pen etc. He also asserts that performance errors are mistakes, adventitious and not serious, because students themselves can correct them when their attention is drawn to them. On the contrary, errors are of importance and the learner would not normally be able to correct them as $\mathrm{s} / \mathrm{he}$ has an incomplete knowledge of the TL structure involved. Also errors are systematic reflect the competence of L2 learner (his lack of knowledge of the TL, i.e., linguistic transitional competence). They refer to idiosyncrasies in the interlanguage of the learner, which are direct manifestations of a system within which a learner is operating at the time. Errors are significant, persistent, and, in consequence, serious; their treatment requiring careful analysis to discover their cause (Ibid, 1986). Richards et al. (1992) state "a learner makes a mistake when writing or speaking because of lack of attention, fatigue, carelessness, or some other aspects of performance. Mistakes can be self-corrected when attention is called", while an error (error of competence) is "the use of linguistic item in a way that a fluent or native speaker of the language regards it as showing faulty or incomplete learning"? In other words, it occurs because the learner does not know what is correct, and thus it cannot be self-corrected. Ellis $(1994$, p. 58) stated that any deviation from the TL norms may reflect either a problem (error) in competence or (mistake) in performance, as illustrated in figure 1. Ellis added that when you ask the learner to correct a mistake and he does not know what is correct, and thus it cannot be self-corrected, it is an error. Similarly, Bose (2002) says that competence errors are caused by the application of the rules of the TL wrongly and the performance errors are the result of mistakes in language use and they occur as false starts, corrections, or slips of the tongue, etc. To sum up, errors are the systematic and regular mistakes committed by the second/foreign language learners at competence level due to linguistic reason.

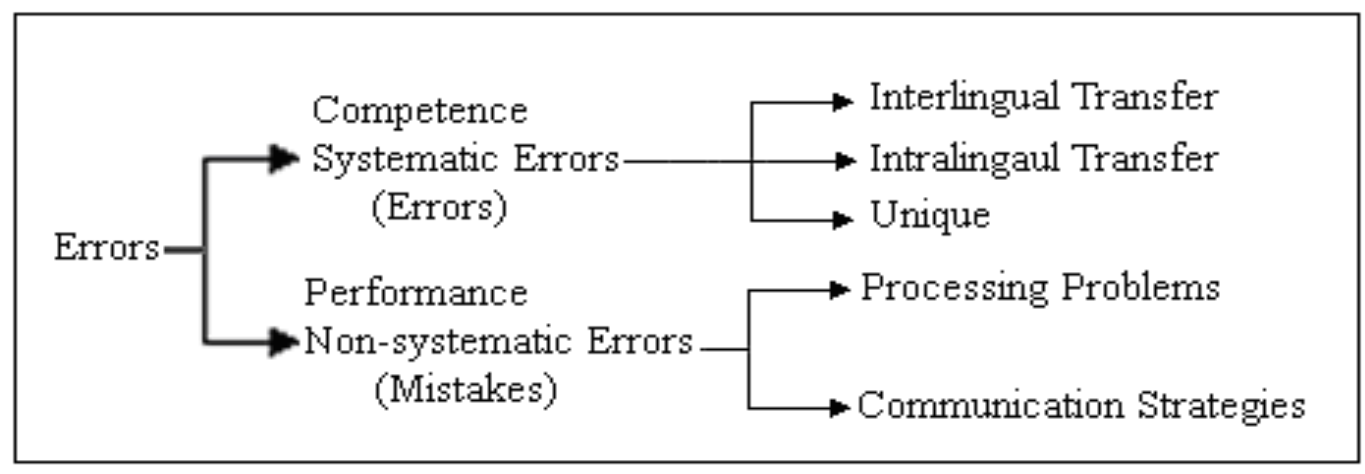

Figure 1. Psycholinguistic sources (adopted from Ellis, 1994, p. 58)

\subsubsection{Pitfalls in Terms of Acceptability or Grammaticality}

Defining errors in terms of acceptability or grammaticality should serve as a criterion. If the latter is chosen, as the case in almost all the reviewed literature in the current study, it is a sine qua non to give consideration to the distinction between overt and covert errors (Ellis, 2005). The criterion of grammaticality at which an error can be defined as reported by linguists, e.g., James (1998); Ellis and Barkhuizen (2005); and based on Corder's (1986), is "a breach of the rule of the code". This is probably the safest definition, although, as James (1998) points out that "it depends on what particular variety of the target language is chosen as the code". This may not be significant where grammar is concerned. While, what constitutes semantic or phonological well-formedness though can vary considerably depending on the variety chosen (Ellis, 2005, p. 56). Acceptability norms depends on the "subjective evaluation" (Ellis, 2005; James, 1998) of the researcher and usually seeks making stylistic than deciding grammatically. Judgments about the approval in terms of acceptability of an utterance/sentence are surely less reliable in the sense that they will be less congruous across researchers. James argues that "when non-linguistic factors militate against the use of form, we attribute this to unacceptability. While it is the knower (NS) of a language who decides whether an utterance is grammatical, it is the user who decides whether an utterance is acceptable" (James, 1998, p. 66). Having shed some light on the endurance of EA as an area of research, and on the definition of errors and types of errors, at this juncture, it plausible to review the previous related literature based on empirical data involving pitfalls made by Arab EFL/ESL learners and what pedagogical implications that they might be obtained of those studies. 


\subsection{EFL/ESL Learning/Acquisition}

The distinction between second and foreign language learning is what learned and how it is learned. Gass and Selinker's (2001) definition of Foreign language learning is the learning of a nonnative language in the environment of one's native language. In second language learning, language plays an institutional and social role in the community. It functions as a recognized means of communication among members who speak some other language as their native tongue. In foreign language learning, language plays no major role in the community and is primarily learned in the classroom. In the context of this study, "L2" can refer to any language that is learned subsequent to mother tongue. Thus, it can refer to third or fourth language, and also "second" in this study is not intended to contrast with "foreign". Whether the language is learned naturally as a result of living in a country where it is spoken, or learning it in a classroom through instruction, it is customary to speak generically of second language acquisition (Ellis, 1997, p. 3). Therefore, in this study, no distinction is made between second and foreign language learning, or between "learning" and "acquisition". Rather, in accordance with Ellis (1997, p. 3) and Lessard-Clouston (2007, p. 3), second language learning is simply seen as the learning of any language after the mother tongue has been acquired. The field of research and theory in applied linguistics deals with learning a second/foreign language (i.e., any language that is not one's mother tongue). The main aim of SLA research involves the description and explanation of the linguistic or communicative competence of the learner (Ellis, 1994, p. 15).

\subsection{The Importance of English in Arab World}

Interest in the teaching of English as a global language has been growing throughout the Arab world, and almost all Arab governments began to introduce the teaching of English as compulsory subject into the school curriculum. This trend has become so popular that there have even been curriculum changes in some parts of the Arab world where languages other than English, particularly French, were traditionally taught in the public system. At present, in most Arab countries, all students who finish the public secondary school education must have had at least eight years of instruction in English as a school subject. So, because of the widespread use of English as a second language, the subject of language teaching in general and teaching English as a foreign or second language in particular, has become the focus of attention of many Arab researchers (Al-Khatib, 2000). The overwhelming majority of the population of Jordan speaks Arabic as their mother tongue, whereas English by both historical accident and present-day consensus is learned as the principal foreign language. Although its importance is well recognized by many individuals, its strongest support comes from the government. To sum up the present status of English in the Arab world, Zughoul rightly states: "despite the hegemonic and imperialistic nature of English, it is still badly needed in the Arab world for the purposes of communicating with the world, education, acquisition of technology and development at large. Teaching still needs more efforts to be exerted to raise the quality and standard of English of the Arab learners at all levels" (Zughoul, 2003, p. 1).

\subsection{A Review of the Related Literature}

This section reviews empirical studies on Arabic-speakers' pitfalls and comments on their contributions to our understanding of Arab EFL learners. Following the trend of current research which tends to focus on the learner himself and the specific areas of difficulty which he encounters in learning EFL/ESL. The researcher will present and comment on these studies conducted EA with the intention shedding some light on the problematic areas on which this study is focused. Usually, students of English as a Foreign Language (EFL) from the same linguistic background encounter common problems.

For the last two decades, several researchers, notwithstanding, the attempts to tackle the difficulties and problems of English language learning/teaching at all levels of education in the Arab world, Arab students still encounter serious problems in their English language. Depicting the situation, for example, of English in Jordan, Abd Al-Haq 1982 (cited in Rababah, 2003, p. 1) rightly states: "there are general outcries about the continuous deterioration of the standards of English proficiency of students among school teachers, university instructors and all who are concerned with English language teaching". This section will provide major types of pitfalls taken from reviewed empirical studies; in other words, the most common syntactic/semantic types of pitfalls encountered by EFL Arab learners. This problem has been clearly emphasized by several researchers (e.g., Tahaineh, 2012, 2011; Mohammed, 2000, 2001, 2005, 2011; Mourtaga, 2004; Bataineh, 2005; Bacha, 2002; AlKhuwaileh \& Al-Shoumali, 2000; Hamdallah, 1988; Obeidat, 1986; Mehdi, 1981). Thereby, the aim of this paper is to offer better insights of the different problems encountered by Arab EFL learners. Pitfalls were reviewed as a rich potential source of a wide range of information which is useful to a variety of people (teachers, students and applied linguists) involved in the language learning process (See section 1.1.1). 


\subsubsection{Prepositions, Articles and Discourse Markers}

This study is a review of syntactic/semantic pitfalls in three areas considered the most difficult sub-categories encountered EFL Arab learners; investigations of errors encountered Arab EFL learners (see 1.4) reveal a similarity of problematic areas in English syntax/semantics. The major problems are found to be in the use of prepositions, articles, discourse markers (DMS, henceforth) respectively. Hence, and for the limited time and room of this research, one main empirical study about each sub-category will be selected as an example. And if it is found that there is a need to clarify a point a little bit more, then the study will quote another example for that sub-area. It is important also to notify here that the way the examples and quotations are taken from the empirical studies as they are without any change for the true description of these pitfalls as they are described and exemplified by the concerned researchers.

\subsubsection{Errors in the Use of Prepositions}

Problems and difficulties of prepositions are witnessed by several scholars: e.g., "Anybody who has taught advanced foreign learners of English is aware that these little abstract, chaotic functions of the prepositions remain a stumbling block long after mastery of essentials has been achieved" (Kreidler, 1966, p. 119). McCarthy (1972) says that as any English teacher well knows, our prepositions are particularly troublesome lot to the nonnative speaker of English. At the same time and level prepositions turn to be a very useful category in language. Prepositions do not just play the role of grammatical maker. They are essential in a number of applications such as indexing and knowledge extraction since they convey basic relationships of much interest like instrument, means, amounts, comparisons, approximations, localizations, etc. In argument structure, they often play the crucial role of a mediator between the verbs' expectations and the semantics of the nominal argument. Prepositions add to the description of the writer's sentence by making important distinctions in meaning, adding writer's information and showing relationships (Popa, 2007). Essberger (2007) has identified a preposition as a word, usually placed before a noun or pronoun to indicate or to show in what relation the person or thing denoted by it stands in regard to something else. Tahaineh (2010) in an empirical study, he investigated kinds of errors committed by EFL Arab undergraduates at Princess Alia University College, in the use of prepositions in their writing production. Data was derived from free compositions written by a stratified random sample of 162 students with similar linguistic, sociocultural, and educational backgrounds. Results revealed that mother tongue interference (MTI) is the major source of EFL learners' errors $(58 \%=1323$ out of 2290$)$. However, transfer strategies of the TL itself are also detected and constituted a major part of the errors too (42\% $=967$ out of 2290). The three types of errors were substitution, addition and omission. Here are some examples cited in Tahaineh's study on Substitution: $\boldsymbol{A} \boldsymbol{t}$ instead of $\boldsymbol{i n}$ : *(1)- . a at the winter the weather is very cold. *(2)at the summer term all students like to take late classes In the sentences (1) and (2), the learners used "at" instead of "in". These errors are attributed to overgeneralization that arises from the uncertainty in the learners' mind, particularly when they face the task of using one preposition to express different relationships and meanings, this is the case, it is not surprising that the learners will overgeneralise one item over the other as in (1) and (2) they overgeneralised the preposition "at" to be used instead of "in". Substitution: By instead of for: *3Amman is famous by its ruins. *4- ... and I paid JD 4,000 by the car. ... (3) 9ammaan mašhuurah bi ?aaقaarihaa $=*$ Amman famous by ruins its $=$ Amman is famous by its ruins. (4) Wa dafa9tu arba9u? aalaaf dinar ?urdunii bi al siyaarah $=*$ “ $\ldots$ and paid I 4000 dinar Jordanian by that the car" $=$ " $\ldots$ and I paid JD 4,000 by the car". The error is attributed to learners' native language. MSA bi or fii = "by" or "in" which can be used interchangeably to indicate ta9liil = to this reason in (3) and to indicate "?il9iwad" = "in return for", in (4). In MSA, the adjective "mašhuur" = "famous", in such context takes "bi" = "by". In brief, first two examples (1 and 2) show Target Language Interference (TLI), while examples (3 and 4) show (MTI). Between instead of among: The following are illustrative examples: *5)- There are many customs between the population of Amman. *6)- “... since language is a mean of communication between the people..." In the foregoing sentences $(5,6)$ some learners used "between" instead "among". The meaning of between and among is very similar, between usually involves two persons or things, some times it involves more than two, when we have definite number in mind, then between is used , e.g., "Jordan lies between Palestine, Syria, Saudi Arabia and Iraq". Whereas, "among" always involves more than two persons or things. Since "between" is the more frequently used one, it is overgeneralized by the learners in the study to convey the meaning of "among" as well. Under instead of at: The following are illustrative examples: *(7)- ... I am under his request. *(8)- he told him that he was under his service *(9)- ... and said, I am ... under your disposal. In the foregoing sentences $(7,8,9)$ the learners' native language impact is very obvious. The MSA preposition tahta "under" is used instead of "at" causing these errors, this transfer took place in form of literal translation since the Arabic version tahta is equivalent to "under". Therefore sentence (7) above translate into MSA, for example, and will have the following counterpart: (7) ... anaa Akuuno tahta 
țalabak $($ ?amrak $)=\mathrm{I}$ am under request your $=\mathrm{I}$ am under your request. Tahaineh continues to say that Arab Jordanian EFL students use the proper prepositions providing equivalents are used in their MT; select the improper prepositions if equivalents are not used in their MT; omit prepositions if equivalents are not required in their MT and add prepositions if equivalents are required in their MT. Several researchers conducted their studies on syntactic pitfalls including prepositions as, a case in appoint, their findings showed that MTI is the major source of their errors which is consistent with Tahaineh's (2010) results. Several other studies of more general nature along the lines of Error Analysis included sections on prepositions (cf., for example, Nakhallah, 2010; Mourtaga, 2004, Mahmoud, 2002; Mohammad, 2000; Lakkis \& Malak, 2000; Diab, 1997; Hamdallah, 1988; Al-Ameedi \& Ameer, 2009; Mukattash, 1986; Obeidat, 1986; Mehdi, 1981; Habash, 1982, among others). In sum, Arab EFL students depend on transfer to judge the suitable usage of prepositions, and the above studies, more or less, agreed that transfer is a major source of errors in prepositional usage made by Arab EFL university learners.

\subsubsection{Errors in the Use of Articles}

One of the problematic aspects of the English noun phrase for native speakers of Arabic is definiteness. Zughoul (2002) in a study about "Interlanguage Syntax of Arabic-Speaking Learners of English: The Noun Phrase": states that the most frequent errors in the noun phrase area are in the use of articles (38\%); they formed $12.5 \%$ of the total number of errors, and he ascribed the majority of errors to learners' L1 interference. In his error analysis study on Arab students, Willcott (1972) concludes that definiteness problems were far more frequent than any other problem in English syntax faced by Arab students. Quirk et al. (1972) points out that "the definite article the and the indefinite article(s) $a(n)$ are two mutually exclusive articles in English". Several Arab researchers (e.g., Zughoul, 2002; Alhaysony, 2012; Crompton, 2011; Salman, 2010; Abu Jarrad, 2008; Bataineh, 2005, among others) conducted research studies on English articles and there was a more or less similar consistency with some differences about the sources/causes of errors in the results they reached. For example, Bataineh (2005) analyzed 209 compositions written by Jordanian Freshmen, Sophomores, Juniors and seniors university EFL students, to identifying the kinds of errors they make in the use of the indefinite article. Nine kinds of error were identified, as: (1) Deletion of the indefinite article, e.g., (a) English is international language [an international language] (b) My neighbor was killed in car accident [a car accident] (2) Writing a as part of the noun/adjective following it, e.g., (a) Shakespeare wrote so much he became afamous [a famous] playwright. (b) Speed is the most common case for alot [a lot] of accidents (3) Substitution of the indefinite for the definite article, e.g., (a) Yarmouk University Street is a commercial center [the commercial center] of Irbid. (b) English may be an only language [the only language] of business (4) Substitution of the definite for the indefinite article a/an or null, e.g., (a) English is spoken by a people [people] from every nation.(b) A students [students] who know English have a better chance in life. (c) The person [a person] needs English for communication. (5) Substitution of a for an, e.g., (a) She broke her arm in a accident [an accident]. (b)He has not a enough time [?] to leave the car. (6) Use of the indefinite article with unmarked plurals, e.g., (a) English is spoken by a people [people] from every nation. (b) A students [students] who know English have a better chance in life. (7) Use of the indefinite article with marked plurals, e.g., (a) ... which are an important cities for ... (important cities) (b) There were an interesting messages ... received from. (interesting messages) (8) use of the indefinite article with uncountable nouns, e.g., (a)Young people use an information [information] to imitate the crimes in movies. (b) I heard a news from him. (heard news) (9) Use of the indefinite article with adjectives, e.g., (a) English is an extensive ... (b)The buildings are all a classical ... Bataineh (2005) ascribed the majority of errors made by the four groups are the result of common learning processes, such as overgeneralization and simplification of the English article system. Also the influence of learners' L1 is found but minimal, learners' L1 led to the deletion of the indefinite article. Diab (1997), Zughoul (2002), Alhaysony (2012), and Abushihab et al. (2011) partially disagree with Bataineh regarding source of error, on the contrary, they ascribed the majority of errors made by EFL Arab learners in the use of English article (definiteness) differences in the expression of reference in English and Arabic, i.e., the differences in the article systems of Arabic and English, in the mean time, the target language (L2) interference is detected too. For more details see the foregoing Arab investigators'.

To sum up: the reviewed literature in this area has shown that the overwhelming majority of EFL/ESL Arab students made numerous such errors, and most of these errors are dependent of the learners' native language. Common learning strategies like overgeneralization and simplification were found to be the next major source of the learners' errors. Besides, the reviewed empirical studies revealed agreement on nine (9) most frequent types of errors as follow respectively: (1)-Deletion of the indefinite article. (2)-Deletion of the definite article. (3)-Use of the indefinite article with adjectives. (4)-Use of the definite article with proper nouns (5)-Use of the indefinite article with uncountable nouns. (6)-Substitution of the definite article for the indefinite article. 
(7)-Substitution of the indefinite article for the definite article. (8)-Substitution of a for an. (9)-Substitution of an for a. Also the reviewed literature emphasized that Arab EFL learners at the tertiary level encounter real difficulties in the use of definite and indefinite articles in their written and spoken discourse. The sources of these errors are varied, but the majority of errors are due to the differences in the article systems of Arabic and English; i.e., most of these errors are dependent of the learners' native language; and common learning strategies like Overgeneralization and Simplification were found to be the next major source of the learners' errors. (For more details see Diab, 1997; Zughoul, 2002; Salman, 2010; Alhaysony, 2012; Abushihab et al., 2011; Abu Jarrad, 2008; Bataineh, 2005).

\subsubsection{Discourse Markers}

Writing is a process which includes thinking planning, developing reviewing, editing and presenting. We highlight the importance of writing in all (Bjork \& Raisanen, 1997, p. 8) university curricula not only because of its immediate practical application, i.e., as an isolated skill or ability, but because we believe that, seen from a broader perspective, writing is a thinking tool. It is a tool for language development, for critical thinking and, extension, for learning in all disciplines. This is a line of thought that should be developed. While there is no room in this research to deal with other studies (e.g., Leki, 1991; Purves, 1988), it is enough to say that these studies enhance the point of interrelatedness between the errors of L1 and L2 with no restriction to Arabic, English or any other languages. Hence, writing in L2 is viewed as a demanding task and for L2 learners to be able to produce discourse that conforms to the norms of discourse created by their native counterparts, and to be familiar with the various components of writing that would assist them to write effectively. Doubtless, that the ability to produce grammatically correct sentences in L2 is important, but awareness of how discourse in L2 is created is also of great importance. Therefore, the awareness of the use and practicality of DMs can enormously contribute to the overall quality of the discourse created by ESL/EFL learners. The word Discourse is defined as "a spoken or written communication between people" and mark is defined as "a sign that is written or printed symbol" (Collins COBUILD Dictionary, 2006). DMs are a type of linguistic phenomenon pervasively used in daily communication. Swan (2005, p. 151) defines discourse as "pieces of language longer than a sentence".

Linguists (e.g., Schiffrin, 1987; Carter, 2007; Swan, 2005) define DMs, each in his own linguistic expressions, for example, Swan (2005, p. 151) gave a simplistic account of DMs saying: "Some words and expressions are used to show how discourse is constructed. They can show the connection between what a speaker is saying and what has already been said or what is going to be said; they can indicate what speakers think about what they are saying or what others have said". Whereas Schiffrin $(1987$, p. 31) defines DMs as "sequentially dependent elements which bracket units of talk". Moreover, Carter (2007, p. 411) defines DMs as "intra-sentential and supra-sentential linguistic units which fulfill a largely non-propositional and connective function at the level of discourse". Plethora of literature on DMs has sought answers as to what DMs are, what they mean and what functions they manifest. Based on the theoretical background under which these markers are discussed and analyzed, they have been given various names. For example, they were referred to discourse connectives (Blakemore, 1987) pragmatic markers (Fraser, 1999), as sentence connectives (Halliday \& Hasan, 1976), just to mention a few instances of DMs are words such as, but, and, also, so, then, actually, well, in fact, furthermore, because, etc.

As long as the present study concerns with the use of DMs in written/spoken discourse as a third and last area to be reviewed and discussed, the following section is to be devoted to a brief discussion of some of the studies that have dealt with the use of DMs in the writings of nonnative speakers of English particularly in EFL context, and Arab learners of the same context. Jalilifar's (2008) conducted a study on 90 EFL Iranian Learners. His participants wrote 90 descriptive compositions. His results showed that Iranian learners used elaborative DMs such as and, furthermore, as well as, in addition to, etc., were the most frequently used, followed by inferential such as according to, so, then, etc., contrastive such as though, but, contrary to, etc., causative such as because, therefore, since, etc., and topic relating markers such as the first thing is, what I would like to do, let's look at, back to, etc. Finding also indicated that the number of well functioned DMs positively contributed to the quality of learners' writing. Jalilifar also argued and suggested that the learners who were better able to appropriately and effectively employ DMs were more successful in producing more coherent writing. Jin (2009) did a study in which she explored the use of contrastive discourse markers (CDMs) by EFL Japanese and Chinese learners. Results of her study showed that the use of CDMs by the study sample was rather restricted to those familiar to them. Some of the functions of but as used by the Chinese and Japanese learners were triggered by their wordfor-word translation from their L1 to L2 (English). Jin ascribed this restricted use of CDMs to the fact that the learners are cautious of making mistakes when using some unfamiliar CDMs. The author ascribed the limited use of DMs to the fact that the explanation of CDMs by writing instructors is inadequate or inappropriate. 
Regarding EFL Arab learners, Modhish (2012) and Yaari et al. (2013) conducted their studies separately at two different times/dates, settings and level of participants of their studies. Modhish (2012) conducted his study on Arab EFL students (150) of tertiary level (juniors) at Taiz University (TU, henceforth), whereas Yaari et al. (2013) conducted their studies on 200 male Arab EFL students selected randomly from 20 public and private schools in Saudi Arabia, at the final year of secondary stage which is nominated as pre-university stage. Modhish's (2012) study was based on the analysis of (150) written essays by EFL Arab university students, while Yaari et al. (2013) their study was based on the analysis of data spontaneously collected via recording the participants' natural speech individually in classroom while they were studying English. Both studies sought answers for these two main questions: (1) what are the DMS that are frequently used by Arab EFL English majors in their essay writings? (2) How and why EFL Arab learners use EDMs the way they do?

Modhish's (2012) study showed that EFL Arab learners have made use of elaborative, inferential, contrastive, causative, and topic relating markers respectively. From their expository writing one can notice that they overused elaborative DMs (204), for instance, and, also, furthermore, as well as, in addition to, etc. Modhish ascribed the extensive use of the elaborative DMs to two main reasons that are: the learner's mother tongue and the nature of the writing task the learners were involved in, which was expository writing. Whereas the occurrence of the marker "and" in particular is evidently noticeable in Modhish's data as he said, and this particular DM is extensively and broadly used in spoken as well as written Arabic, therefore, the learners were relying on their L1 when they produced their writing. Modhish's results indicated that learners' knowledge of discourse markers is limited and showed that there is no strong positive correlation between the DMs employed by the learners in their compositions and the quality of their written production. Moreover, Modhish said that his participants tended to make use of DMs that they are pretty sure of how to use them and would not take the risk of trying to use some of the unfamiliar ones. Furthermore, Modhish stated that there was one main cause has to do with the fact that learners get obsessed with the grammaticality of the sentences they produce and their ideas that they want to express; such obsession resulted very little room for DMs. Besides, their limited and restricted knowledge of DMs indicated that DMs are not given the due importance they deserve by their grammar and writing teachers. Modhish asserted that the topic relating markers such as the first thing is, what I would like to do, let's look at, back to, etc., are shown to be strongly positively correlated with the writing quality of the learners, correlation is significant at 0.05 which means those learners who were able to appropriately and correctly employ those topic relating markers produce relatively better writings. To sum up, Modhish stated the following reasons which lead his EFL Arab learners encounter difficulties in using DMs: (1) The use of DMs is restricted and limited to those familiar to the learners. (2) The poor quality of their writing can also be ascribed to the grammatically erroneous sentences that they have produced, i.e., learners are generally weak in grammar too. (3) They depend on literal translation from their mother tongue into target language while writing their composition and that is what made them use the conjunction and which is evidently noticeable in their writing and this particular DM is extensively and broadly used in spoken as well as written Arabic. (4) Most of learners employ DMs which they pretty sure of how to employ them and did not take the risk of using the unfamiliar ones. (5) Some learners are afraid of committing errors so they feel reluctant to venture with DMs that are unfamiliar to them (6) Learners are obsessed with the accuracy (grammaticality) of the sentences they produce. (7)Another cause, it seems that English writing instructors and EFL teachers in general, do not give DMs the due importance they deserve, hence, very little place is left for DMs. Modhish's findings go in line with the findings of the previously conducted research that the use of DMs by EFL learners is rather limited and this affects the quality of their writings (Rahimi, 2011; Jin, 2009; Jalilifar, 2008; Martinz; 2004). Additionally, Modhish's study, however, indicates that the use of DMs is restricted to those familiar to the learners and these DMs did not seem to have a positive impact on the quality of learners' writings.

The other study which I selected is Yaari et al. (2013) who conducted their study on 200 male Arab EFL students selected randomly from 20 public and private schools in Saudi Arabia, at the final year of secondary stage which is nominated as pre-university stage. Yaari et al. (2013) their study was based on the analysis of data spontaneously collected via recording the participants' natural speech individually in classroom while they were studying English. Recordings were then linguistically and statistically analyzed by the researchers. Yaari et al. (2013) says that the purpose of their present study is to explore how this linguistic phenomenon is used by Saudi EFL learners. More specifically, the study seeks answers to the following questions: (1) what are the DMS that are frequently used by Arab EFL English majors in their written/spoken discourse in comparison to those EFL learners from English speaking countries? (2) How and why EFL Arab learners use DMs the way they do? Finding is to some extent consistent with other studies on discourse markers regarding the learners of EFL context with little discrepancies of EFL non-Arab learners like Spanish, Chinese and Hungarians and these discrepancies are ascribed to the differences of the use and usage of their discourse markers in their respectable 
languages and when they employ the EDMs they do literal translation of what they usually employ in their native language.

Findings of Yaari et al. (2013) show that EDMs "and", "but" and "also" are the most frequent EDMs among Saudi EFL learners. Recordings show that "and" has been repeated 514 tokens (Mean = 14.7), "but" and "also" were repeated, according to the recordings, 232 and 212 tokens respectively (Means $=2.57,1.16$, and 1.07 respectively). For EDMs "besides", "therefore" and "yet", results show that they are the least frequent EDMs with 94, 27and 17 tokens (Means $=0.47,0.13$ and 0.08 respectively). Findings also show that EDMs "so", "because", and "however" fall in the middle between EDMs "and", "but" and "also" and "besides", therefore" and "yet". Score frequencies for these four EDMs are: 178, 132 and121 tokens with means $0.89,0.66$ and 0.60 for each. Outcomes also show that EFL learners do not use the same EDMs used by learners from other English native speaking countries. In fact, even Saudi EFL earners used these EDMs in different ways. For example, "and" proves to be the most frequent EDMs used by G.2 (S.51-100) who used it 154 tokens. The same device has been used 47 tokens by G.4 (S.151-200). The same groups used the EDM "yet" 6 tokens and 1 token respectively. Yaari et al. (2013) tried to summarize the analysis of their students' pitfalls of the oral spontaneous discourse recordings saying that such paper of this length cannot completely reply questions of how and why Arab EFL Saudi Learners unable to use EDMs correctly, but they state that one who is really interested in EDMs usage and use by Arab EFL Saudi might find some answers and further information about reasons of these difficulties in some translation and Grammar books (for instance, Al-Sijistānī, 616 A.H.; Al-Zamakhsharī, 1993; Al-Jurjān̄̄, 1983; IbnJinn̄̄, 1985; Azar \& Hagen, 2006; Groen et al., 2010) and because some reasons are related to problems in translation level, Arab learners are advised to go through translation books (e.g., Shunnaq, 1983), and some research papers discuss the difficulties EFL Arab learners face when they try to translate extensions and uses of EDMs (see for example: Tahaineh, 2011; Hussein et al., 2008; Al-Khresheh, 2011; Saeed \& Fareh, 2006). For instance, Tahaineh (2011) conducted an empirical study named "Pitfalls Encountered by Bilingual Arab Learners in Translating the Arabic Discourse Marker (ADM) "Oumma" into English" Findings revealed that the improper translation of functions of the Arabic DMs is still prominent among Arab learners of English. Here are some examples Tahaineh cited in his study, with regard to Arabic DM "Oumma" 1- Layla tadrus-u. Oumma bada?a tasaaqot al-amțaar = Layla is studying. And then it has started raining. The ADM Oumma was erroneously rendered by $36 \%$ of the subjects as "and", $11 \%$ as "also" and $10 \%$ as comma, zero (nothing) respectively. The faulty responses indicate that the subjects failed to recognize the logical relationship holding between the two sentences. The faulty use of and or also instead of the intended meaning of the target language text. Moreover, the wrong use of the comma leads to the formation of a run-on sentence, a feature that is unacceptable in formal written English. 2- tar9aa al?ummu abnaa?ah-aa hatta yakbaruu Oumma laa talqaa minhum mo9aamala hasana! = The mother takes care of her children until they grow up; nevertheless, she does not receive the good treatment from them. The analysis of the data indicated that $31 \%$ of the subjects inappropriately translated "Oumma" into "and". Furthermore, $4 \%$ of the subjects wrongly used comma, semicolon instead of "Oumma". Anyhow, all the faulty responses and, semicolon, comma, employed by translation students as a replacement of Oumma do not precisely capture the intended meaning of this Arabic DM. He concludes that the translation of the ADM "Oumma" was, on the whole, not easy. The average percentage of the correct responses was $62 \%$, which means that more than $1 / 3(38 \%)$ of the total responses was incorrect. In general, there is no oneto-one correspondence between two languages in the field of DMs: most of the time their correlates in the target language have not the same pragmatic meaning, constituting a usual pitfall in translation. This may be especially true if these languages are genetically unrelated, as is the case with Arabic and English. Consequently, DMs should constitute a major component of a larger whole in the syllabus of translation courses. EFL Learners should be trained to recognize and identify the role that EDMs play in entailing/indicating logical relations between clauses and sentences in discourse. Since determining the function that a DM signals in discourse is usually governed by the context in which the DM is used; in a translation context where semantic precision has a high priority, EFL learners and translators should consider that an extra meaning is there, not because of the semantic aspects of the words themselves, but because the reader/hearer shares certain contextual knowledge with the writer/speaker of the text. The foregoing researchers, with regard to EDMs, recommend further crosslinguistic work in this area, including other Arabic DMs such as $f a$, wa, innama, lakinna, bal bainama, lakin, etc., and their English counterparts which can be an interesting and fruitful topic to the real needs of EFL learners, translators and translator educators in a post-colonial world. Yaari et al. (2013) referring to the outcomes of analyses for EDMs frequencies, they found that EFL Arab Saudi Learners used EDMs less than other EFL learners, their conclusion is supported by evidence from the numbers of the frequencies, they cited , just for example, Hungarian uses EDMs "well", (415 tokens) "so" (338 tokens), "but" (290 tokens), "yes" (264 tokens), "no" (194 tokens), "and" (149 tokens), "then" (114 tokens), “yeah" (100 tokens), "thus" (98 tokens), 
"let's say" (83 tokens), "so that" (68 tokens), "good" (56 tokens), "incidentally" (54 tokens), and "let me see" (53 tokens) (Der \& Marko, 2010).

\subsection{By Way of Conclusion}

This study is set out to review types of pitfalls made by EFL Arab university students in the use of the most three problematic syntactic/semantic sub-categories: prepositions, articles and discourse markers, respectively, in written and oral discourse. The review reveals that EFL Arab learners at the tertiary level experience serious difficulties in using the correct prepositions, articles and discourse markers, respectively.

\subsubsection{Preposition}

The prepositions proved to be the most common in use and the most difficult ones for EFL Arab Learners are : by, in, on, to, with, of, from, for and at respectively. Mother tongue interference (MTI) is a learning strategy that most foreign-language learners fall back on especially in acquisition-poor classroom situations where exposure to the language is confined to a few hours per week of formal instruction. The majority of errors made by the subjects are the result of their mother tongue interference as the major source $(1323$ errors $=58 \%)$ of the total errors 2290). These findings lend support to previous research studies (e.g., Khodabandeh, 2007; Velloo, 2000; Zahid, 2006; Mohammad, 2005; Mahmoud, 2002; Hamdallah, 1988; Mehdi, 1980, among others) who have confirmed that the majority of errors made by the EFL learners are because of the impact of MTI, which was found to play an outstanding role. The data shows that the subjects select the improper prepositions if equivalents are not used in their mother tongue; delete prepositions if equivalents are not required in their mother tongue, add prepositions if equivalents are required in their mother tongue and use the proper English prepositions providing equivalents are used in their mother tongue. Whereas, transfer strategies of TL itself constitute the second major source of errors $(967$ errors $=42 \%)$ such as overgeneralization (analogy) and ignorance of rule restrictions appeared the most possible twofold cause of intralingual errors. While overgeneralization and transfer errors may not be qualitatively different for the class levels, they were found to be quantitatively different. Tahaineh (2012) states that his findings are consistent with results of previous studies on Arabic-speaking learners of English. He added that Learners' whose native language is Arabic face two particular difficulties, stemming from (1) An Arabic preposition is equivalent to more than one English preposition. (2) Interference from the native language which is related directly to the problem of literal translation from Arabic into English. Pedagogically, these adult learners could be made aware of this transfer strategy and its outcome. Cases of positive and negative transfer could be discussed with them so that they know when to transfer and when not to. There is no doubt that, more exposure to the language through reading and listening is necessary. Tahaineh (2012) says that although the results achieved in his study are sound and significant, more research is needed. He suggests a longitudinal study using subjects from four class levels (freshmen, sophomores, juniors and seniors) over the period of their study might prove invaluable for these purposes, not to mention incorporating oral as well as written data in the analysis. Finally, in respect of this problem, indeed, a serious collaborative effort needs to be made here by all concerned, including teachers, learners, researchers and material writers alike. It is also proper to state here that if measures are not taken to overcome this problem as difficulties in using prepositions or any other parts of the English grammar beforehand, then such issues will build up to become a major issue which will be too difficult or too late to undertake simultaneously. Pitfalls provide feedback (Corder, 1973, p. 265) they inform the teacher about the effectiveness of his teaching material and his teaching techniques and show him what parts of syllabus he has been following inadequately learned or taught and need further attention. Pitfalls enable the teacher to decide whether he must devote more time the item he has been working on. Pitfalls provide information for designing a remedial syllabus or program of teaching. Another finding from this study is that, when learners are encountered with inherent complexities of TL, they will overgeneralise, analogize, and simplify, etc., to reduce their learning burden. When they overgeneralise, for instance, they rely on a TL rule of great generic and which they already know; this results in avoiding learning the appropriate rule and inevitably results in pitfalls. For example, the occurrence of the preposition "in", in the phrases like "in detail, in fact, in high spirit, in reality, in the room", etc., lead them to use "in" in a phrase like "in the other hand" which reflects their way of thinking, this may appear more logic led them to use "in" in such positions. This way of thinking is more persistent in the use of prepositions associated with verbs, nouns and adjectives, the student may think that because the verb, for example, "choose" does not take a preposition in a sentence like : "I choose my friend Layla as the best girl" so; he/she omits the preposition in a sentence like: "to arrange ${ }^{\wedge}$ him everything" or "he depends on his parents to choose $^{\wedge}$ him the girl", or, like "he showed me new novel" leads to "he explained me his new novel". It is believed that the insights gained from the study of learners' pitfalls in the use of prepositions can provide invaluable information for devising appropriate materials and effective teaching techniques. Finally, the 
identification of the prepositional problem, its uses and constructions in the study can help text book designers and curriculum specialists by providing them with the information that can help them in designing a remedial syllabus or a programme of teaching including pedagogical grammar.

\subsubsection{Articles}

The article system of English is one of the most difficult structural components for EFL Arab learners; it occupies the second position in rank regarding difficulty especially for those whose native languages do not employ articles or article-like morphemes Zughoul (2000). Whereas Master (2002) attributes the difficulty, of English article system, into three factors: (a) The function words "a/n and the" are among the most frequent function words in English (Celce-Murcia \& Larsen-Freeman, 1999), making constant rule application difficult over an extended stretch of discourse; (b) function words are usually unstressed and consequently are very difficult for non-native speakers to distinguish, which affects the availability of input in the spoken mode; (c) the English article system stacks up several functions onto a single morpheme, which forms a considerable burden for the learner who usually looks for a one-to-one correspondence between form and function, especially in the early stages of language learning. Most of all reviewed studies, regarding the acquisition of the English article system by Arab learners in EFL context (e.g., Kharma, 1981; Zughoul, 2002; Alhaysony, 2012; Bataineh, 2002), agreed that the major reason behind committing pitfalls is native language transfer, i.e., mother tongue interference which in this case is Arabic. Bataineh (2005) conducted a study at the same context of Yarmouk University in Jordan and found native language transfer plays a role which is at best minimal, and this result contradicts to some extent with other studies and even with her own earlier analysis (2002) where she found that native language transfer was found to play a major role behind committing pitfalls; whereas Bataineh's (2005) study revealed that all errors, except one, are independent of the learners' native language. The only type of error which could be traced back to the native language transfer, i.e., the influence of Arabic deletion of the indefinite article. Bataineh (2005) states some developmental reasons and some common learning processes such as simplification, overgeneralization and analogization were found to account for the majority of learners' pitfalls. The use of the mentioned strategies was evident among all the EFL learners of the four class-level of seniors, juniors, sophomores and freshmen respectively. On the contrary, Kharma (1981), Bataineh (2002), Zughoul (2002), Alhaysony (2012), Salman et al. (2010), Hamza and El-Hilli (2011) attributed the errors of EFL Arab learners in using the English article system to a few causes and sources, but almost all of them agree that the major source is interlingual, i.e., the interference of mother tongue which is in this case is Arabic. For example, Alhaysony (2012) investigated the use of the definite and indefinite articles by EFL Arab Saudi female learners at Ha'il University in the Kingdom of Saudi Arabia employing the Surface Structure Taxonomies (SST) of errors. Data were collected from written samples of 100 first-year female EFL students at the Department of English in the University of Ha'il. Her findings showed that the omission of the indefinite article "a/an" was committed most frequently. Further, addition errors are the second most frequent, and the addition of the definite article "the" seems to be the most frequent of such errors. Also, Alhaysony (2012) restated in many places in her research that the interlingual errors are the most significant, supporting Brown (2000) whose idea is that interlingual errors are most significant. Arab Researchers (cf. Kharma, 1981; Bataineh, 2002; Zughoul, 2002; Alhaysony, 2012; Salman et al., 2010; Hamza \& El-Hilli, 2011) contend with what they call a fact that that EFL writing instructors need to remember that students are to be treated with sensitivity and consideration, they should remember that they are not error hunters, but that their job is to create a non-threatening classroom by convincing students that they can write, that writing can be learned, and that nobody's writing is perfect. Thus, criticizing students' composition should be avoided and praising them is vital. Also English instructors have to clarify the differences between L1 and L2 in the use of definite and indefinite articles of English. The Arab researchers of the English Article system believe that sufficient practice of English writing and a proper method of teaching English grammar are the best solutions to eliminate, or at least reduce, the writing errors of Arab EFL learners. Besides, instructors of English must adjust their techniques or even change them if necessary to cater to the needs of their learners, and it is writing that makes them feel brave, enhances self-esteem and confidence, increases positive feeling, and makes them think of themselves as writers. A longitudinal study using the same subjects over the period of their study might prove invaluable for these purposes, not to mention incorporating oral as well as written data in the analysis. A plea is made for more research on EFL Arabic learners at tertiary level.

\subsubsection{Discourse Markers}

The Arab researchers whom I have reviewed (e.g., Hamdan \& Fareh, 1999; Yaari et al., 2013; Tahaineh, 2011; Hussein et al., 2008; Al-Khresheh, 2011; Saeed \& Fareh, 2006; Rahimi, 2011; Modhish's, 2012) investigated the problems and difficulties encounter EFL Arab Learners in the use of discourse markers in written and oral 
discourse. These researchers met and contended to say that evidence in the literature of applied linguistics indicates that learners have their own systems of rules for the production of the foreign language that they practise. It suggests that they use various heuristics and strategies both to acquire these rules and to use them in communicative processes. Also most of them are on line with the idea that mother tongue interference (MTI) is a learning strategy that most foreign-language learners fall back on (Tahaineh, 2010) especially in acquisition-poor classroom situations where exposure to the language is confined to a few hours per week of formal instruction. Supporting this idea, Selinker (1983, p. 3) states, "the phenomenon of interlingual transfer has been somewhat like a pendulum, swinging from all to nothing, and now finally settling somewhere in the middle".

However, the Arab and non-Arab researchers investigating EDMs difficulties in EFL context recommend further research with more corpora and different methodology. Therefore, next studies should focus on how EDMs are used in both written and oral work of Arab EFL learners in comparison to other EFL as well as English native speakers. The quality of the essays written by the learners can be viewed as poor and this reveals that writing is not sufficiently dealt with by many EFL programs in the Arab world. In other word, the restricted use of DMs on the part of the learners indicates that such an important component of any writing course is apparently neglected.

Therefore, adequate exposure to such linguistic items is very crucial for learners, i.e., the discourse markers, need to be tackled explicitly and implicitly by writing instructors. Accessibility of such markers to the learners will enable them to produce coherent and cohesive essays. Consequently, the explicit and implicit teaching of DMs should be an integral part of writing courses offered to EFL learners. It is advisable that the EFL programs in the Arab world and in the other similar contexts treat writing as a separate skill and not to be looked at as a secondary skill that is not given the attention it deserves. Most of the Arab researchers I have reviewed in this study suggest a more detailed study that should look into the nature of DMs in Arabic would provide EFL instructors in the Arab world with some important clues and insight into how such linguistic items are used. Such detailed study would help design teaching materials that would tackle the problems face Arab EFL learners and to draw their attention to the importance of DMs in enabling them to produce coherent and cohesive compositions. One important thing is a contrastive analysis of DMs in English and Arabic would certainly prove fruitful for the teachers of writing skill in this part of the world. It is hoped that this kind of research would add another building block to the research work concerned with the difficulties encountered by Arab EFL learners when they attempt to compose in English. EFL learners at tertiary level, do not usually have much difficulty in understanding certain rules or classifications, but when they need to apply them they sometimes fail to do so. As Goldman and Murray (1992, p. 505) rightly state "ESL students frequently are very good in reciting the prescriptive rules of usage for various [conjunctions]," but to master the appropriate use of conjunctions is "extremely difficult".

\section{Pedagogical Implications and Future Directions}

The result of reviewing difficulties in the three problematic areas: prepositions, articles and discourse markers and the foregoing observations about these three areas inspire and motivate the formulation of the following pedagogical implications to EFL learners and their teachers, translators and to the process of teaching translation in addition to some fruitful suggestions and future directions:

Pitfalls in the use of prepositions, articles and discourse markers can provide invaluable information for devising appropriate materials and effective teaching techniques. Its uses and constructions in the study can help text book designers and curriculum specialists by providing them with the information that can help them in designing a remedial syllabus or a programme of teaching including pedagogical grammar. It is strongly suggested that a syntactic structure such as the English coordination structure "and" should be given much attention by Arab EFL teachers. Since the findings of this study shed light on the difficulties that EFL learners encounter in translating the prepositions, articles and DMs it might be helpful, in teaching writing courses, to focus on the use of intra/inter-sentential relations as well as the devices used to create these connections. EFL teachers should make their students aware of areas of differences between Arabic and English syntactic structures. Apparently, differences between L1 and L2 may make the process of acquiring the L2 more difficult and complicated for Arab EFL learners. The EFL Arab learners, of the empirical studies I reviewed in this study, use their L1 as a learning strategy in their learning of English. In other words, they use such a strategy in order to solve their learning and communication problems which face them while learning the three problematic areas: preposition, articles and discourse markers, respectively. The use of Prepositions, Articles or DMs is restricted and limited to those familiar to the learners and the poor quality of their writing can also be ascribed to the grammatically erroneous sentences that they have produced, i.e., learners are generally weak in grammar too, besides, they depend on literal translation from their mother tongue into target language while writing their composition or producing oral discourse, and this because Arab EFL learners are obsessed with the accuracy (grammaticality) of 
the sentences they produce, and it seems that English writing instructors and EFL teachers in general, do not give these three problematic areas the due importance they deserve, hence, very little place is left for them.

Interlingual transfer is a learning strategy that most of the EFL learners of this study fall back on, especially in acquisition-poor classroom situations where exposure to the language is confined to a few hours per week of formal instruction. Moreover, it is significant that the English basic prepositions, articles and DMs which correspond directly to Arabic that are well used and mastered. This further suggests the dependency on MT. In other words, the improper use of Prepositions, Articles and DMs is prominent among EFL Arab learners, even at advanced stages of their learning. It is one of the areas where LI interference is very evident and very important factor in foreign/second language learning, and should be taken into account when second language learners' performance is investigated. There is also sufficient evidence in the reviewed studies to characterize interference as a cognitive learning strategy in which learners apply prior knowledge and experience to the second language itself to overcome the gaps in their knowledge, when fail to find the desired item in the L2. However, other errors in the use of the three problematic areas: Prepositions, Articles and DMs due to intralingual source are also identified; the developmental factors and common learning strategies like overgeneralization, analogy and simplification, and possibly communication strategies as avoidance were found to account for the learners' intralingual errors. This study has looked at the concept of interlangauge, which sees learners as constructing their own grammatical systems. These systems are learner-driven rather than teacher-driven, the learner progresses through employing a number of different strategies, some of which are based upon her/his L1, some of which are based upon her/his desire to communicate, and some of which may be rooted in the Universal Grammar. Universal grammar is another source of learners' difficulties. Some hierarchies of acquisition are not unique to a particular target language, but arise from universal cognitive limitations on the complexity of structures. Certain structures are inherently more complex than others, and thus take longer to be acquired cross linguistically; this is evidenced by the acquisition of prepositions Article and DMs respectively as a late event in language acquisition.

The inclusion of cultural material in the curricula is significant for increasing students' motivation and interest in the foreign language, for improving the learners' communicative competence. Since language is an integral part of culture, understanding cultural aspects becomes essential to language learning, and the classroom is probably the most efficient place for those who have no access to the environment of the target language culture to absorb it. This will eventually help learners avoid the semantic complexities of their L1 when communicating in L2. Minimal exposure to the TL will hinder learning especially in EFL context. Further research on what school teachers are actually doing in their classrooms vis-à-vis what the syllabus requires is worthy of investigation. This review mainly deals with the linguistic factors contributing to under-achievement in using English Prepositions, Articles and DMs, therefore, further research is recommended for investigating intelligence and motivation to determine whether they contribute to Arab EFL learners' under-achievement in using prepositions. Articles and DMs.

To conclude, the identification of the Preposition, Article and DMs problem, their uses and constructions in the reviewed empirical studies can help text book designers and curriculum specialists by providing them with the information that can help them in designing a remedial syllabus or a programme of teaching including pedagogical grammar. Also similar studies could be conducted not only with different samples of adult Arab learners of EFL, but also with learners of EFL from different first-language backgrounds, to see to what extent the committing pitfalls could be attributed to the role of language universals in second/foreign language acquisition. Further research should take into consideration socio-linguistic factors such as settings, motivation, attitudes, etc., in order to ascertain if they would play significant roles in second language learning and whether there is a relationship between such factors and the committed errors. Finally, from the studies have been reviewed in this research study EA has yielded interesting findings regarding EFL Arab learners. Contrary to popular belief, EA is far from being exhausted. Several covert errors are still waiting for the right approach, to be ferreted out. If we are to make L2 learning operates more efficiently and effectively all position related to the discovery, identification, interpretation and explanation of L2 learners' errors should be explored.

\section{References}

Abi-Samra, N. (2003). An analysis of errors in Arabic speakers' English writings. American University of Beirut, Lebanon. Accessed April 2, 2007.

Abu-Jarad, H. (2008). Evaluating Grammar Development through Longitude Error Analysis of English Major Students. Aqsa University Journal, 12(2), 54-68.

Al-Abdan, A. A. (1993). A study on using Arabic in teaching English in Saudi intermediate schools. King Saud 
University Magazine, 50(2), 396-426.

Al-Batal, M. (1990). Connectives as cohesive elements in a modern expository Arabic text. In M. Eid, \& J. McCarthy (Eds.), Perspectives on Arabic Linguistics II. Amsterdam: John Benjamin.

Alderson, C. J. (1981). Introduction. In J. C. Alderson, \& A. Hughes (Eds.), Issues in Language testing. London: The British Council.

Al-Haq, A. (1982). An Analysis of Syntactic Errors in the Composition of Jordanian Secondary Student (Unpublished master's thesis). Yarmouk University, Jordan.

Alhaysony, M. (2012). An Analysis of Article Errors among Saudi Female EFL Students: A Case Study. Asian Social Science, 8(12). http://dx.doi.org/10.5539/ass.v8n12p55

Al-Khatib, M. (2000). The Arab world: Language and cultural issues. Language, Culture, and Curriculum, 13(2), 121-125. http://dx.doi.org/10.1080/07908310008666593

Al-Khresheh, M. H. (2011). An Investigation of Interlingual Interference in the use of "and" as a Syntactic Coordinating Structure by Jordanian EFL Learners. European Journal of Social Sciences, 18(3).

Al-Khresheh. (2011). An Investigation of Interlingual Interference in the use of "and" as a Syntactic Coordinating Structure by Jordanian EFL Learners. European Journal of Social Sciences, 18(3), 426-433.

Al-Khuwaileh, \& Shoumali. (2000). Writing Errors: A Study of the Writing Ability of the Arab Learners of Academic English and Arabic at University. Language, Culture, Curriculum, 13(2), 174-183. http://dx.doi.org/10.1080/07908310008666597

Alshayban, A. S. (2012). Copula omission by EFL Arab learners (Unpublished master's thesis). Colorado State University Fort Collins, Colorado.

Al-Shormani, M. (2010). Semantic errors committed by Arab learners of English: Classifications an L1 and L2 Sources. CALTS, University of Hyderabad, India. Retrieved September 14, 2010, from http://www.scribd.com/doc/25280229

Al-Yaari, S. A. S. et al. (2013). Using English discourse markers (EDMs) by Saudi EFL learners: A descriptive approach. International Journal of English Language, 1(2).

Bacha, N. N. (2002). Developing learners' academic writing skills in higher education: A study for educational reform. Language \& Education, 16(3), 161-177. http://dx.doi.org/10.1080/09500780208666826

Bataineh, R. F. (2005). Jordanian Undergraduate EFL Students' Errors in the Use of the Indefinite Article. Asian EFL Journal, 7(1), 1-20.

Bjork, L., \& Raisanen, C. (1997). Academic writing: A university writing course. Lund: Student literature.

Bose, M. (2002). English language teaching in Yemen (ELT) for yemeni students. Yemen: Obadi studies and publishing centre.

Brown, H. D. (2000). Principles of language learning and teaching. New Jersey: Prentice Hall.

Burt, M., Dulay, H., \& Krashen, S. D. (1982). Language two. Rowley MA: Newbury House.

Carroll, J. B. (1981). Specifications for an English language testing service. In J. C. Alderson, \& A. Hughes (Eds.), Issues in language testing. London: The British Council.

Celce-Murcia, M., \& Larsen-Freeman, D. (1999). The grammar book: An ESL teacher's course. Boston: Heinle and Heinle.

Chomsky, N. (1965). Aspects of the theory of syntax. Cambridge, Mass: MIT Press.

Chomsky, N. (1966). Linguistic theory. North-east conference on the teaching of foreign languages. In J. P. B. Allen, \& P. van Buren (Eds.), Chomsky: Selected Readings. Oxford: Oxford University Press.

Collins Cobuild Advanced Learners English Dictionary on CD-Rom. (2006). Harper Collins publishers.

Comrie, B. (1990). Second language acquisition and language universals research. Studies in Second Language Acquisition, 12, 209-218. http://dx.doi.org/10.1017/S0272263100009098

Concise Oxford Dictionary on CD-Rom. (10th ed.). (2001). Oxford University Press.

Corder, S. P. (1973a). Introducing applied linguistics. Harmondsworth: Penguin Education.

Corder, S. P. (1986). Error Analysis and Interlanguage. Hong Kong: Oxford University Press. 
Crompton, P. (2011). Article errors in the English writing of advanced L1 Arabic learners: The role of transfer. Asian EFL Journal. Professional Teaching Articles, 50.

Dessouky, S. (1990). Error analysis: A non-stop area of Research. Studies in Curricula and Methodology, 8, 146-176.

Diab, N. (1997). The transfer of Arabic in the English writings of Lebanese students. The ESP, Sao Paulo, 18(1), 71-83.

Dulay, H., Burt, M., \& Krashen, S. (1982). Language Two. New York: OUP.

Eckman, F. (1991). The structural conformity hypothesis and the acquisition of consonant clusters in the interlanguage of ESL learners. Studies in Second Language Acquisition, 13, 23-41. http://dx.doi.org/10.1017/S0272263100009700

Ellis, R. (1994). The study of second language acquisition. Oxford: Oxford University Press.

Ellis, R. (1997a). Second language acquisition. Clearendon St. Oxford: Oxford University Press.

Ellis, R., \& Barkhuizen, G. (2005). Analyzing learner language. Oxford: Oxford University Press.

Erdogan, V. (2005). Contribution of error analysis to foreign language teaching. Mersin University Journal of the Faculty of Education, 1(2), 261-270.

Essberger, J. (2007). English Prepositions List. Retrieved August 14, 2008, from http://www.esldepot.com/product.php/14/5/

Fowler, H. (1906). The king's English. Oxford: Clearendon Press.

Fraser, B. (1999). What are discourse markers? Journal of Pragmatics, 31, 931-952. http://dx.doi.org/10.1016/S0378-2166(98)00101-5

Gass, S. M., \& Selinker, L. (1994). Second language acquisition: An introductory course. New Jersey: Lawrence Erlbaum Associates. http://dx.doi.org/10.1017/S0272263100013097

George, H. V. (1972). Common errors in language learning insights English. Rowly, Mass: Newbury House Publishers.

Goldman, S. R., \& Murray J. D. (1992). Knowledge of connectors as cohesion devices in text: a comparative study of native-English and English-as-a-second language speakers. Journal of Educational Psychology, 84(4), 504-519. http://dx.doi.org/10.1037/0022-0663.84.4.504

Halliday, M. A. K., \& Hasan, R. (1976). Cohesion in English. London: Longman.

Hamdallah, R. W. (1988). Syntactic errors in written English: Study of the errors made by Arab students of English (Unpublished doctoral dissertation). University of Lancaster, UK .

Hamza, A. A., \& El-Hilli, S. E. (2011). Errors Made By IRAQI EFL Non-Departmental Undergraduates in Using Definite \& Indefinite Articles.

Howard, G. (1994). The good English guide. London: Macmillan.

Hussein, M., \& Bukhari, N. (2008). Discourse markers and procedural meaning: The case of Fa in standard Arabic.

Jalilifar, A. (2008). Discourse Markers in Composition Writings: The case of Iranian learners of English as a $\begin{array}{llll}\text { foreign language. English } & \text { Language }\end{array}$ http://dx.doi.org/10.1016/S0378-2166(98)00101-5

James, C. (1998). Errors in language learning and use. London: Longman.

Jindal, D. V., \& Syal, P. (1999). An introduction to Linguistics: Language, grammar and semantics. New Delhi: Prentice Hall of India.

Kharma, N. (1981). Analysis of the errors committed by Arab university students in the use of the English definite/indefinite articles. IRAL, 14(4), 335-345.

Klassen, J. (1991). Using students' error for teaching. English Teaching Forum, 34(1), 10-16.

Kreidler, C. W. (1965). English Prepositions. ELT, 20(2).

Lado, R. (1957). Linguistics Across Cultures. Ann Arbor: University of Michigan Press.

Leki, I. (1991). Twenty years of contrastive rhetoric texts analysis and writing pedagogies. TESOL Quarterly, 25, 
123-143. http://dx.doi.org/10.2307/3587031

Lessard-Clouston, M. (2007). SLA: What it offers ESL/EFL teachers. Retrieved May 17, 2008, from http://www.catesol.org/07Lessard-Clouston.pdf

Lightbown, P. M., \& Spada, N. (2006). How Languages are Learned. Oxford: Oxford University Press.

Mahmoud, A. (2002). Interlingual transfer of idioms by Arab learners of English. The Internet TESL Journal, $8(12)$.

Mahmoud, A. (2011). The Role of Interlingual and Intralingual Transfer in Learner-centered EFL Vocabulary Instruction. AWEJ, 2(3), 28-49.

Mahmoud, A. M. (2005). Collocation Errors Made by Arab Learners of English. Asian EFL Journal: English Language Teaching and Research Articles, 5.

Major, R., \& Faudree, M. (1996). Markedness universals and acquisition of voicing contrasts by Korean speakers of English. Studies in Second Language Acquisition, 18, 69-90. http://dx.doi.org/10.1017/S0272263100014686

Martinez, A. C. L. (2002). The use of Discourse Markers in EFL learners' Writing. Revista Alicantina de Estudios Ingleses, 15, 123-132.

Master, P. (2002). Information structure and English article pedagogy. System, 30, 331-348. http://dx.doi.org/10.1016/S0346-251X(02)00018-0

McCarthy, K. (1972), Teaching English Prepositions. TEFL, 6.

Mehdi, M. (1981). The interference of Arabic in the use of English prepositions (Unpublished doctoral dissertation). University of Texas at Austin, USA.

Modhish, A. S. (2012). Use of Discourse Markers in the Composition Writings of Arab EFL learners. English Language Teaching, 5(5), 56-61.

Mohammed, A. (2000). MSA vs. NSA: Where do Arab Students of EFL Transfer From? Language, Culture and Curriculum, 13(2), 126-136. http://dx.doi.org/10.1080/07908310008666594

Mohammed, A. M. (2005). Collocation errors made by Arab learners of English. Asian EFL Journal. Teachers Articles, 5(2), 117-126.

Mourtaga, K. (2004). Investigating writing problems among Palestinian students: Studying English as a foreign language. Bloomington, Indiana, Author House.

Obeidat, H. A. (1986). An investigation of syntactic and semantic errors in the written composition of Arab EFL learners (Unpublished doctoral dissertation). University of Illinois at Urbana Champaign, USA.

POPA, O. G. (2007). Logically structure English grammar (2nd ed.). Corollary Theorems Ltd.

Purves, A. (1988). Writing across languages and cultures: Issues in contrasti rhetoric. Newbury Park, CA: Sage.

Quirk, R., Greenbaum, S., Leech, G., \& Svartik J. (1985). A comprehensive grammar of the English language. London: Longman.

Rabab'ah, G. (2003). Communication problems facing Arab learners of English. Journal of Language and Learning, 3(1), 180-197.

Rahimi, M. (2011). Discourse Markers in Argumentative and Expository Writing of Iranian EFL Learners. World Journal of English Language, 1(2), 68-78. http://dx.doi.org/10.5430/wjel.v1n2p68

Richards, J. C. (2002). Longman dictionary of applied linguistics. London: Oxford University Press.

Richards, J. C., Platt, J., \& Platt, H. (1992). Longman dictionary of language teaching and applied linguistics. London: Longman Group Ltd.

Saeed, A. T., \& Fareh, S. (2006). Difficulties encountered by bilingual Arab learners in translating Arabic "fa" into English. The International Journal of Bilingual Education and Bilingualism, 9(1), 19-31. http://dx.doi.org/10.1080/13670050608668628

Salman, D. S., \& Shihab, S. S. (2010). An Analysis of Errors Made by EFL Students of Basrah Women-Teacher Training Institute in the Area of Definite and Indefinite Articles.

Schiffrin, D. (1987). Discourse Markers. Cambridge: Cambridge University Press. http://dx.doi.org/10.1017/CBO9780511611841 
Selinker, L. (1992). Rediscovering interlanguage. London: Longman.

Swan, M. (2005). Practical English Usage. Oxford: Oxford University Press.

Swan, M., \& Smith, B. (2001). Learner English: A teacher's guide to interference and other problems (2nd ed.). Cambridge Handbooks for Language. http://dx.doi.org/10.1017/CBO9780511667121

Tahaineh, Y. (2011). Pitfalls Encountered by Bilingual Arab Learners in Translating the Arabic Discourse Marker 'Oumma' into English. Theory and Practice in Language Studies, 1(3), 226-238. Finland: Academy Publisher. http://dx.doi.org/10.4304/tpls.1.3.226-238

Tahaineh, Y. (2012). Jordanian EFL undergraduates' syntactic pitfalls: With particular reference to prepositions. International Journal of Applied Linguistics \& English Literature, 1(6), 297-314.

Turton, J., \& Heaton, N. (Eds.). (1996). Longman dictionary of common errors. London: Longman.

Wahba, E. (1998). Teaching Pronunciation-Why? Language Teaching Forum, 36(3), 32.

Weir, J. C. (1981). Reaction to the Marrow Paper (1). ELT Document, 2, 26-37.

Whitman, R., \& Jackson, K. (1972). The unpredictability of Contrastive Analysis. Language Learning, 22(1), 29-41. http://dx.doi.org/10.1111/j.1467-1770.1972.tb00071.x

Willcott, P. (1978). Problems of definiteness in the written English of Arabic speakers. English Language Teaching Journal, 33(1), 67-73. http://dx.doi.org/10.1093/elt/XXXIII.1.67

Ying, S. (2009). Remarks on Contrastive Discourse Markers (CDMs) in Writings by non-native English learners. US-China Foreign Language, 7, 40-46.

Zughoul, M. R. (2002). Interlanguage Syntax of Arabic-Speaking Learners of English: The Noun Phrase. Retrieved from ERIC database (ED479649).

Zughoul, M. R., \& Abdul-Fattah, H. (2003). Translational Collocational Strategies of Arab Learners of English. Babel, 49(1), 59-81. http://dx.doi.org/10.1075/babel.49.1.05zug

\section{Copyrights}

Copyright for this article is retained by the author(s), with first publication rights granted to the journal.

This is an open-access article distributed under the terms and conditions of the Creative Commons Attribution license (http://creativecommons.org/licenses/by/3.0/). 